\title{
Prospective Evaluation of Transsphenoidal Pituitary Surgery in 108 Patients with Cushing's Disease
}

\begin{abstract}
Transsphenoidal pituitary surgery (TSS) remains the treatment of choice for Cushing's disease (CD). Despite the widespread acceptance of this procedure as the first line treatment in $C D$, the indication of a second TSS in not cured or relapsed DC patients is not consensus. We report the results of TSS in 108 patients with CD (a total of 117 surgeries). The mean postoperative follow-up period was 6 years. Remission was defined as clinical and laboratorial signs of adrenal insufficiency, period of glucocorticoid dependence, serum cortisol suppression on oral 1-mg dexamethasone overnight suppression test and clinical remission of hypercortisolism. We evaluated 103 patients with CD by the time of the first TSS. Fourteen patients underwent second TSS ( 5 had already been operated in others centers; in 5 patients the first surgery was not curative; in 4 patients $C D$ relapsed). Remission rates were $85.4 \%$ and $28.6 \%$ ( $p<0.001$ ) after first and second TSS, respectively. In microadenomas, remission rates were higher than macroadenomas $(94.9 \%$ vs. $73.9 \% ; p=$ $0.006)$. In patients with negative pituitary imaging remission rates were $71.4 \%(p=$ 0.003 ; vs. microadenomas). Postoperative complications were: transient diabetes insipidus, definitive diabetes insipidus, hypopituitarism, stroke and one death. Only hypopituitarism was more frequent after second TSS ( $p=0.015)$. In conclusion, TSS for $C D$ is an effective and safe treatment. The best remission rates were observed at the first surgery and in microadenomas. The low remission rates after a second TSS suggest that this approach could not be a good therapeutic choice when the first one was not curative. (Arq Bras Endocrinol Metab 2007;51/8:1355-1361)
\end{abstract}

Keywords: Cushing's disease; Transsphenoidal pituitary surgery; Remission rates

\section{RESUMO}

Avaliação Prospectiva da Cirurgia Hipofisária Transesfenoidal em 108 Pacientes com Doença de Cushing.

O tratamento de escolha para a doença de Cushing (DC) ainda é a cirurgia transesfenoidal (CTE) para ressecção do adenoma hipofisário produtor de ACTH. Porém, a indicação de uma segunda CTE representa uma questão controversa, tanto nos pacientes não curados após a primeira cirurgia quanto nos casos de recidiva. Neste trabalho, relatamos os resultados da CTE em 108 pacientes com DC (totalizando 117 cirurgias). O tempo médio de seguimento foi de 6 anos. Critérios de cura: ocorrência de insuficiência adrenal (clínica ou laboratorial), período de dependência ao glicocorticóide, supressão do cortisol sérico pós-1 mg de dexametasona overnight e remissão clínica do hipercortisolismo. Foram avaliados 103 pacientes com DC submetidos à primeira CTE. Quatorze pacientes foram submetidos a uma segunda CTE ( 5 já tinham sido operados em outros centros; a primeira cirurgia não fora curativa em 5; 4 pacientes com recidiva da DC). Índices de cura: $85,4 \%$ e $28,6 \%$ ( $p<0,001$ ) após a primeira e segunda CTE, respectivamente. Nos microadenomas, remissão maior que nos macroadenomas $(94,9 \%$ vs. $73,9 \%$; $p=0,006)$. Nos pacientes com imagem hipofisária negativa, cura foi de $71,4 \%(p=0,003 ;$ vs. micro). Complicações pós-operatórias: diabetes insipidus transitório e definitivo, hipopituitarismo, acidente vascular cerebral e um óbito. Apenas a ocorrência de hipopituitarismo foi mais freqüente após a segunda CTE $(p=0,015)$. Assim sendo, a CTE para a DC representa uma terapêutica efetiva e segura. Os melhores índices de cura foram obtidos na primeira cirurgia e em microadenomas. O baixo índice de cura após a segunda CTE sugere que esta abordagem não deve ser considerada uma boa opção terapêutica quando a primeira cirurgia não for curativa. (Arq Bras Endocrinol Metab 2007;51/8:1355-1361)

Descritores: Doença de Cushing; Cirurgia transesfenoidal; Índices de cura

\section{artigo original}

\author{
GUILHERME ROLLIN \\ NeLSON PIREs FerReIRA \\ Mauro A. Czepielewski
}

Division of Endocrinology, Hospital de Clínicas de Porto Alegre, Programa de Pós-Graduação em Ciências Médicas: Endocrinologia e Nutrição, Faculdade de Medicina, Universidade Federal do Rio Grande do Sul (GR \& MAC); and Division of Neurosurgery, Hospital São José, Irmandade da Santa Casa de Misericórdia (NPF), Porto Alegre, RS.

Recebido em 03/10/07

Aceito em 10/10/07 
C USHING'S DISEASE (CD) is a relatively rare but debilitating endocrinopathy associated with increased morbidity and mortality (1-3). The diagnosis and treatment of CD remains a formidable challenge. Currently, the treatment of choice for CD is transsphenoidal pituitary surgery (TSS) resulting in long-term remission rates of $64-93 \%$, with the highest success rates in patients harboring well-defined microadenomas and lower rates in those with macroadenomas or with no adenoma visible on magnetic resonance imaging (MRI) (4-48). The mortality rate of TSS is less than $1 \%$, and morbidity is approximately $1.8 \%$ in major published series $(4-28,42-51)$.

In cases of surgical failure, repeat exploration of the sella represents a treatment option that has been advocated by some centers $(23,27,44,45,49,52-54)$. Repeat surgical treatment several days after the first TSS allows the surgeon to reexplore the sella with minimal additional trauma and no major concern about altered surgical anatomy (49). In this situation, some authors recommend a similar procedure used in the first surgery (selective transsphenoidal pituitary surgery) or total hypophysectomy $(23,27,49)$. Nevertheless, some patients could experience a late decrease in cortisol levels and the strategy of immediate reoperation could be unnecessary $(4,39)$.

The aim of this current study was to assess the initial remission rate and long-term outcome in patients who underwent transsphenoidal surgery for Cushing's disease. In addition, we wished to compare the results from the first and second TSS.

\section{PATIENTS AND METHODS}

Since 1989, 108 CD patients who were submitted to TSS at our institution were assessed as to remission rate. In eight patients (seven cured and one not cured) the diagnostic workup and follow-up were performed at other centers and were not considered for evaluation of postoperative cortisol levels. They were considered only for initial remission rate and clinical data. Of the 108 patients, 5 had already been submitted to surgery at others centers and 3 were not cured. These 5 patients underwent a second surgery at our institution. TSS was also repeated in 5 patients originally operated on at our institution because cure was not achieved with the first surgery. Four additional patients were submitted to a second surgery for relapse of CD after 2, 4.5, 5, and $5.5 \mathrm{yr}$, respectively. Thus, 108 patients underwent a total of 117 surgeries (figure 1 and tables 1-3). The study protocol was approved by the Ethics Committee at Hospital de Clinicas de Porto Alegre, and all the patients agreed to participate in the study.

Cushing's syndrome was diagnosed (55) after admission based on increased levels of urinary free cortisol (UFC),

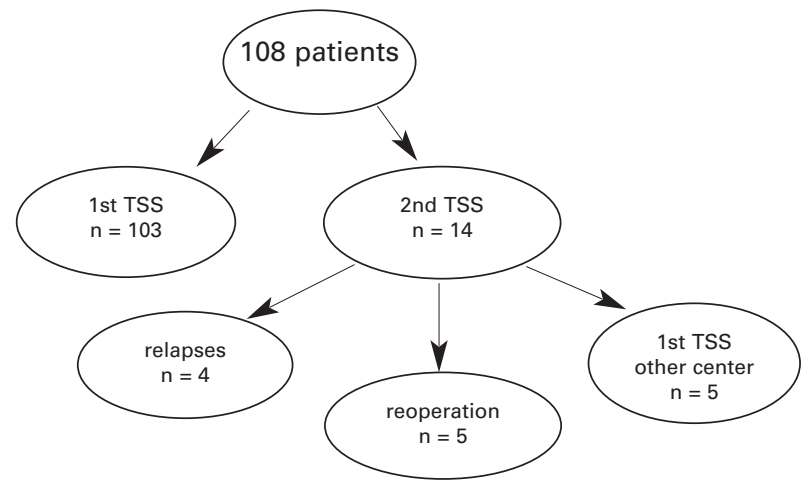

( $n=108 ; 83 F / 25 M$; $12-68$ years

Figure 1. General surgeries indications in 108 patients with Cushing's disease.

Table 1. Clinical data: 108 patients with Cushing's disease.

\begin{tabular}{lr}
\hline central obesity or weight gain & $106 / 108(98 \%)$ \\
facial plethora & $76 / 108(70 \%)$ \\
hypertension & $80 / 108(74 \%)$ \\
acne or hirsutism & $67 / 108(62 \%)$ \\
skin hyperpigmentation & $48 / 108(44 \%)$ \\
diabetes mellitus & $42 / 108(39 \%)$ \\
easy bruisability & $45 / 108(42 \%)$ \\
proximal myopathy & $40 / 108(37 \%)$ \\
abdominal striae & $32 / 108(30 \%)$ \\
psychological disorders & $17 / 108(16 \%)$ \\
kidney stones & $11 / 108(10 \%)$ \\
\hline
\end{tabular}

Table 2. Hormonal and imaging evaluation in 108 patients with Cushing's disease.

\begin{tabular}{lr}
\hline Elevated UFC & $102 / 108(94 \%)$ \\
Midnight serum cortisol > 7.5 $\mu \mathrm{g} / \mathrm{dl}$ & $88 / 88(100 \%)$ \\
No cortisol suppression (serum and/or & $58 / 74(78 \%)$ \\
urinary) 2-mg dexa & \\
Suppression cortisol (serum and/or & $71 / 8(89 \%)$ \\
urinary) 8-mg dexa & \\
Suppression cortisol (serum and/or & $05 / 05(100 \%)$ \\
urinary) 16-mg dexa & \\
Elevated basal ACTH & $40 / 70(57 \%)$ \\
Increase ACTH > 50\% after DDAVP & $67 / 70(96 \%)$ \\
Macroadenoma & $23 / 108(21 \%)$ \\
Empty Sela & $04 / 108(3.7 \%)$ \\
Normal Pituitary Imaging & $17 / 108(16 \%)$ \\
Negative Pituitary Imaging (Normal + & $21 / 108(19 \%)$ \\
Empty Sela) & \\
\hline
\end{tabular}

loss of diurnal rhythm (midnight serum cortisol > $7.5 \mu \mathrm{g} / \mathrm{dl}$; $207 \mathrm{nmol} /$ liter), and/or lack of suppression of UFC and serum cortisol after oral low-dose dexamethasone suppression testing [UFC > $20 \mu \mathrm{g} / 24 \mathrm{~h} ; 55 \mathrm{nmol} / 24 \mathrm{~h}$ and/or serum cortisol $>5 \mu \mathrm{g} / \mathrm{dl}(138 \mathrm{nmol} /$ liter $)$ after oral administration of $0.5 \mathrm{mg}$ dexamethasone every $6 \mathrm{~h}$ for $48 \mathrm{~h}$ ]. If serum cortisol or UFC levels were suppressed after the lowdose dexamethasone suppression test, the diagnosis of CD was based on the presence of at least three of the following: no suppression of serum cortisol in the overnight l-mg dexamethasone test, persistently elevated UFC, midnight 
Table 3. Recurrence in 108 patients with Cushing's disease.

\begin{tabular}{lccccc}
\hline Patient & Pituitary Image & Histology & Cortisol After TSS & Glucocorticoid Dependence & Time to Recurrence \\
1 & Macro & Adenoma & $3.2 \mu \mathrm{g} / \mathrm{dl}$ & 4 months & 66 months \\
2 & Micro & Adenoma & $1.2 \mu \mathrm{g} / \mathrm{dl}$ & 7 months & 60 months \\
3 & Micro & Adenoma & $2.5 \mu \mathrm{g} / \mathrm{dl}$ & 14 months & 54 months \\
4 & Micro & Adenoma & $1.3 \mu \mathrm{g} / \mathrm{dl}$ & 2 months & 24 months \\
5 & Macro & Adenoma & $5.2 \mu \mathrm{g} / \mathrm{dl}$ & 1 month & 36 months \\
6 & Micro & Normal & $1.0 \mu \mathrm{g} / \mathrm{dl}$ & 3 months & 26 months \\
\hline
\end{tabular}

(2400 h) cortisol levels above $7.5 \mu \mathrm{g} / \mathrm{dl}$ (207 nmol/liter), high or upper-normal plasma ACTH levels, and/or an ACTH increase above $50 \%$ after iv 1 -disamino-d-arginine vasopressin (DDAVP) administration.

Diagnosis of pituitary-dependent CD (55) was based on suppression of UFC and serum cortisol in the oral highdose dexamethasone suppression test (UFC and/or serum cortisol suppressed by more than $50 \%$ of baseline values after oral administration of $2 \mathrm{mg}$ dexamethasone every $6 \mathrm{~h}$ for $48 \mathrm{~h}$ ), normal or slightly elevated plasma ACTH, an ACTH increase of at least $50 \%$ after DDAVP administration, and/or circumscribed low-intensity/density lesion on pituitary magnetic resonance imaging or computed tomography scans. The indication for inferior petrosal sinus sampling (IPSS) was related to equivocal results of the endocrinological tests and the MRI. This study was considered confirmatory of pituitary Cushing's disease when the basal central to peripheral ACTH ratio was 2 or more or the DDAVP-stimulated central to peripheral ACTH ratio was 3 or more. The test was considered positive for lateralization when the side-to-side ACTH ratio was greater than 1.4. Long-term follow-up of the patients submitted to TSS confirmed the preoperative diagnosis of CD.

The postoperative assessment of the first 29 surgeries consisted of measurement of serum and urinary cortisol at 10-12 d after the procedure (protocol I). Serum cortisol was collected $48 \mathrm{~h}$ after the last $0.5 \mathrm{mg} / \mathrm{d}$ dose of dexamethasone. Prednisone in $5 \mathrm{mg} / \mathrm{d}$ doses was administered orally for 5-6 $\mathrm{d}$ after surgery, followed by dexamethasone $0.5 \mathrm{mg} / \mathrm{d}$ thereafter. Intravenous hydrocortisone was administered intraoperatively $(100 \mathrm{mg})$ and every $6 \mathrm{~h}$ for $48 \mathrm{~h}(50 \mathrm{mg})$. Patients with low or undetectable serum and/or urinary cortisol levels were maintained on glucocorticoid therapy until recovery of the adrenal-pituitary axis. Patients underwent subsequent overnight oral 1-mg dexamethasone suppression testing at least once a year. After analysis of the first 29 surgeries, the postoperative assessment protocol was changed (protocol II). During the last 88 surgeries, patients did not receive glucocorticoid until adrenal insufficiency was detected clinically or through laboratory tests. Serum cortisol was measured preoperatively and at 6,12 , and $24 \mathrm{~h}$ postoperatively. Exogenous steroids were administered to patients whose serum cortisol levels were under $5.0 \mu \mathrm{g} / \mathrm{dl}(138 \mathrm{nmol} /$ liter $)$ and in those with clinical signs of adrenal insufficiency.

After the first $24 \mathrm{~h}$ after surgery, serum cortisol was measured every day until glucocorticoid therapy was initiated. Ten to $12 \mathrm{~d}$ after surgery, serum and urinary cortisol was assessed as in protocol I. Postoperative remission or cure of $\mathrm{CD}$ was defined by the presence of clinical and laboratory signs of adrenal insufficiency, glucocorticoid dependence, serum cortisol levels under $3.0 \mu \mathrm{g} / \mathrm{dl}(82.8 \mathrm{nmol} /$ liter $)$ at $0800 \mathrm{~h}$ after administration of $\mathrm{l}-\mathrm{mg}$ oral dexamethasone at $2300 \mathrm{~h}$, and clinical remission of hypercortisolism.

Cortisol was measured using a commercially available RIA kit (Diagnostic Systems Laboratories, Inc., Webster, TX) with intra- and interassay coefficients of variation of $8.3 \%$ and $9.8 \%$, respectively, and a lower detection limit of $0.3 \mu \mathrm{g} / \mathrm{dl}(8.3 \mathrm{nmol} /$ liter $)$. The normal range for $24-\mathrm{h}$ UFC was 20-90 $\mu \mathrm{g}$ (55-248 nmol). A competitive chemiluminescent immunoassay (Automated Chemiluminescence System, Bayer Diagnostics, Tarrytown, NY) was used to measure serum cortisol during the first $24-72 \mathrm{~h}$ after surgery [intraand interassay coefficients of variation of $6.0 \%$ and $8.4 \%$, respectively; a lower detection limit of $0.2 \mu \mathrm{g} / \mathrm{dl}(5.5$ nmol/liter)]. ACTH was measured by a chemiluminescent enzyme immunometric assay (Immulite, Diagnostic Products Corporation, Los Angeles, CA), with intra- and interassay coefficients of variation of $5.6 \%$ and $7.75 \%$, respectively, and a lower detection limit of $5.0 \mathrm{pg} / \mathrm{ml}$ (1.1 pmol/liter).

For categorical variables, differences were analyzed by means of the $\chi^{2}$ test. The level of significance was set at $P$ $=0.05$.

\section{RESULTS}

Among the 103 patients who underwent primary TSS at our institution, $88(85.4 \%)$ were regarded as cured. TSS was repeated in the early postoperative period in 5 patients, but they were not cured. In 4 patients, CD recurred 2, 4.5, 5 and $5.5 \mathrm{yr}$, respectively, after the first TSS, and only two patients were cured by repeat surgery. From the 5 patients who have been submitted to TSS at another center, only two were cured after repeat surgery (figure 2). The female-to-male ratio was 83:25. The mean age was $37 \mathrm{yr}$ (range, 12-68 yr). Nine patients were $18 \mathrm{yr}$ old or younger. The mean body mass index was $30.6 \mathrm{~kg} / \mathrm{m}^{2}$ (range, $21.7-56.8 \mathrm{~kg} / \mathrm{m}^{2}$ ), and the mean duration of symptoms was $3.4 \mathrm{yr}$ (range, $0.3-10 \mathrm{yr}$ ). The mean follow-up was 6 yr (range, 2-220 months).

The clinical features of CD patients and preoperative hormonal data and imaging results are shown in tables 1 and 2 . From 18 patients who underwent IPSS preoperatively, a central to peripheral ACTH gradient was detected in 17 (94.4\%). From 103 


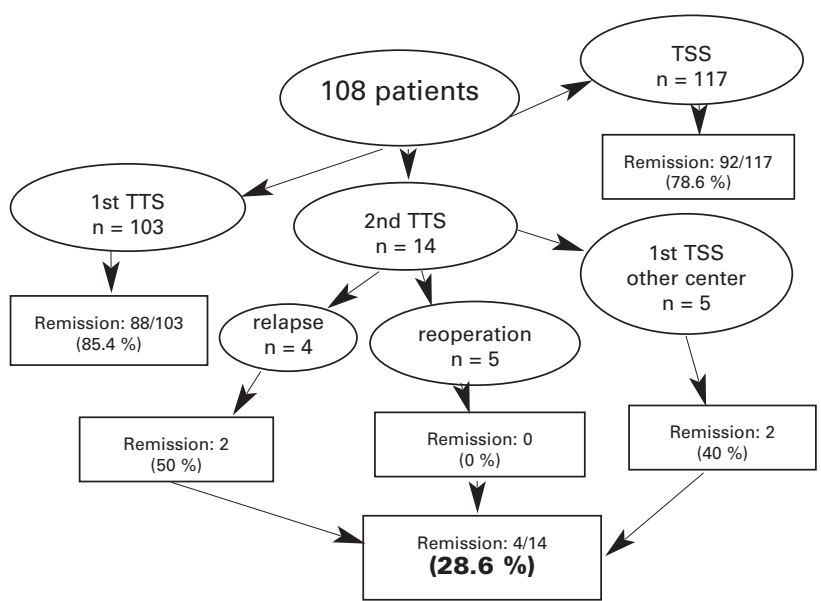

Figure 2. Transsphenoidal surgery in 108 patients with Cushing's disease.

patients who underwent primary TSS, recurrence was detected in $6(5.5 \%)$ (table 3 ).

Remission rates and complications of primary and secondary TSS surgery are shown in figure 2 and table 4. After primary TSS the initial remission rate was $85.4 \%$ and after secondary TSS it was $28.6 \%$ ( $\mathrm{p}<$ 0.0001 ). Second TSS was associated to higher rates of hypopituitarism $(\mathrm{p}=0.015)$. Remission rates were higher in patients with microadenoma when compared to macroadenoma $(p=0.006)$. In patients with negative pituitary imaging remission rates were lower than in patients with microadenoma $(\mathrm{p}=0.003)$ (table 5 ).

Diagnosis of micro/macroadenoma was based on imaging and/or surgical findings. The same surgeon (NPF) performed all surgical procedures at least $2 \mathrm{wk}$ after the diagnostic work-up (including dexamethasone suppression tests). A sublabial approach was used in all patients. All patients received prophylactic antibiotics (trimethoprim-sulfamethoxazole) for 3-4 days. An adenoma was identified during all TSS, except one. Tissue was obtained for histological analysis in all 117 surgeries (108 patients). Histology confirmed the presence of adenoma in 97 patients, with a histological finding of hyperplasia in 1 patient and normal tissue in 10 patients.

\section{DISCUSSION}

Our results, with remission rate of $85.4 \%$ after first TSS, confirm this approach as an effective first-line treatment for CD. Primary TSS has high success rate and low morbidity and mortality rates. On the other hand, a second surgery is associated to lower remission rate $(28.6 \%)$ with higher prevalence of hypopituitarism, especially when total hypophysectomy was applied.
Over the last several decades, advances in microsurgical technique and accumulated experience by pituitary surgeons have resulted in generally excellent results for patients with $\mathrm{CD}$. Remission rates since 1980 have ranged from $40-50 \%$ to $93 \%(5,8$ $12,14,16,17,20-24,26,27)$, with the highest rates of $86-98 \%$ in patients with MRI-defined noninvasive microadenomas treated with primary transsphenoidal tumor removal $(4,12,20,25,26,28-32)$. In this series, although follow-up was relatively short, the overall sustained remission rate was $79.5 \%$ and was 91,75 , and $50 \%$ for the subgroups of patients with microadenomas, macroadenomas, and those with no adenoma visible on MRI, respectively. Our series demonstrated similar results, with initial remission rates of $94.9 \%$ and $73.9 \%$ for microadenomas and macroadenomas, respectively. However, in patients with negative imaging the remission rate was higher than others series: $71.4 \%$ (table 2).

There is still no widespread agreement regarding the definition of apparent cure, and the remission rates after such surgery vary according to the criterion used and the time of assessment. Indeed, the definition of cure and the prognostic effect of subtle or unrecognized residual hypercortisolism have a major clinical impact on the follow-up and therapeutic decisions in patients with CD. Most series from major centers quote remission rates of $70-90 \%$, defining remission as a series of normal postoperative cortisol levels, either as a mean of serial serum cortisol measurements, obtained throughout the day, of $5.4-10.8 \mu \mathrm{g} / \mathrm{dl}$ (150-300 nmol/liter), or as a UFC in the normal range, associated with resolution of clinical stigmata. However, the long-term follow-up of such patients shows a significant incidence of recurrence $(25 \%$ at 10 yr) $(1,14,43,46)$. We adopted stricted remission criteria, including adrenal insufficiency, glucocorticoid dependence, cortisol suppression after l-mg overnight dexamethasone suppression test and clinical remission of hypercortisolism. Even with these remission criteria, we detected a very good remission rate $(85.4 \%)$ with low incidence of recurrence $(5.5 \%)$.

Recurrence rates for CD range between 0 and $26 \%$, with most large studies reporting recurrence rates between 5 and $15 \%$, and a median time to recurrence of 33-59 months $(8,11,21,28,36,54)$. Despite the success of TSS for the treatment of CD, in a number of cases, an ACTH-staining pituitary adenoma is not identified histologically. The clinical significance of lack of histological confirmation remains unclear. Some reports indicate that histological adenoma confirmation significantly affects remission rates, with 
Table 4. Comparison of primary and secondary transsphenoidal surgery in Cushing's disease.

\begin{tabular}{lccc}
\hline & First TSS & Second TSS & p \\
Remission & $88 / 103(85.4 \%)$ & $4 / 14(28.6 \%)$ & $<0.001$ \\
Transient DI & $60 / 103(58.2 \%)$ & $8 / 14(57.1 \%)$ & 0.937 \\
Definitive DI & $1 / 103(1.0 \%)$ & $1 / 14(7.1 \%)$ & 0.095 \\
Hypopituitarism & $32 / 103(31.1 \%)$ & $9 / 14(64.3 \%)$ & 0.015 \\
Stroke & $1 / 103(1.0 \%)$ & $1 / 14(7.1 \%)$ & 0.095 \\
Death & $1 / 103(1.0 \%)$ & $0 / 14(0.0 \%)$ & 0.711 \\
\hline
\end{tabular}

remission rates in patients without histological confirmation of tumor resection ranging between 36 and $69 \%(18,28,46)$. Invitti et al. (46) found remission rates were markedly lower in patients in whom an adenoma could not be identified histologically (36\% vs. $75 \%, \mathrm{p}<0.01)$, but they report no significant difference in recurrence rates. Although it was reported only a $5 \%$ recurrence rate at an average follow-up of more than 3 years (21), current results indicate a recurrence rate in this population corresponding to the upper range of that reported in the literature. Moreover, the timing of recurrence and incidence of early recurrence (at 2,3, and 4 months) appears to be a unique feature of these patients without histological adenoma confirmation (53). In our series, we have only 6 patients with recurrent $\mathrm{CD}$. From these, on only one the adenoma was not identified histologically. The limited number of patients with recurrent CD did not permit any conclusion about recurrent rates in patients without histological adenoma confirmation.

Sonino et al. (43) concluded that surgical failure is associated significantly with failure to identify a pituitary adenoma in the surgical specimen. Pouratian et al. (54), reported remission rate of $50 \%$ in patients without histological adenoma confirmation, a figure lower than their entire series (79\%) and for patients with histological confirmation of an ACTH-staining adenoma $(88 \%)(\mathrm{p}<0.001)$. Similarly, several groups have reported that histological confirmation of an adenoma is significantly more likely in patients who achieve remission than in patients with persistent disease $(35,56)$. The lower remission rate in patients without histological evidence of an adenoma is most likely a result of a decreased rate of adenoma extirpation. The incidence of early recurrence may be a unique feature of this patient population; patients without histological confirmation of tumor resection therefore require close and consistent monitoring postoperatively (54). Despite these reports of differences in outcomes related to histological findings, other groups have found indistinguishable remission rates between these two groups $(26,57)$.
Table 5. Remission rates vs. adenoma volume and imaging in 103 patients with Cushing's disease.

\begin{tabular}{lr}
\hline Total: & $85.4 \%(88 / 103)$ \\
Microadenoma & $94.9 \%(56 / 59)$ \\
Macroadenoma & $73.9 \%(17 / 23)$ \\
Negative Imaging & $71.4 \%(15 / 21)$ \\
Chi-Square Tests p $=0.006^{\mathrm{a}} \mathrm{p}=0.003^{\mathrm{b}} \mathrm{p}=0.853^{\mathrm{c}}$ \\
\hline a Microadenoma vs. Macroadenoma \\
b Microadenoma vs. Negative Imaging \\
c Macroadenoma vs. Negative Imaging
\end{tabular}

It is becoming apparent that long-term results of transsphenoidal surgery may not be as favorable as previously thought and that success rates drop during long-term follow-up. Indeed, the risk of relapse persists for at least $10 \mathrm{yr}$ after surgery, if not longer. This fact, and possible ongoing subtle abnormalities in patients in apparent remission and with the risks of surgically induced hypopituitarism, warrant serious discussion regarding the results of surgery, and also emphasize the need for stringent and indefinite follow-up of these patients (1). The goal of the treatment is the complete resection of the pituitary adenoma with correction of hypercortisolism without inducing permanent pituitary deficiencies. In our series we reported a higher incidence of hypopituitarism (31\% after first TSS) than others series $(4,33,34)$. However, the relapse rate was low, only $5.5 \%(6 / 103)$ during a mean follow-up of 72 months. Thus the overall sustained remission rate in our series was $79.6 \%$, higher than reported in most series (4-28). Our good remission rate with low recurrence could be associated to aggressive pituitary gland exploration and tumor resection inducing pituitary deficiencies in many patients.

The absence of secondary adrenal insufficiency 4-6 wk postoperatively suggests that the patient either has persistent hypercortisolism or most likely will have a recurrence. Some neurosurgeons have even advocated reoperation and more complete hypophysectomy within a few days of the initial surgery in patients whose basal cortisol levels fail to suppress satisfactorily (49). Although this may be successful, there are not yet many published data regarding this aggressive approach. Furthermore, even in patients who clearly have a clinical and biochemical remission (preceded by secondary adrenal insufficiency), there is a recurrence rate of $5-25 \%$. Consequently, there are many patients with $\mathrm{CD}$ who either fail initial pituitary surgery or have a recurrence $(3)$.

The increase morbidity and mortality in patients with Cushing's disease is related to the hypercortisolism and rarely the ACTH-secreting pituitary tumor 
per se. Therefore, the most important treatment goal must be ameliorating the excessive cortisol secretion. In many patients with recurrent or persistent CD, offering a repeat pituitary operation may be a reasonable approach, particularly in those with abnormalities on pituitary MRI. Again, there are very few published data on reoperation in Cushing's disease, but the remission rates are clearly less than those in the initial operation $(49,53)$. Locatteli et al. (49) suggested that immediate reoperative TSS for DC should be considered a safe and effective strategy. In Locatteli's series, 8 of 12 patients had no tumor found at the second operation, and 5 had surgical remission. They explained this phenomenon by the loss of the pathological material in the operative suction apparatus or in transport or handling in the pathology laboratory. We do not agree with these conclusions and explanations. Our results on reoperation are disappointing, with remission rate of only $28.6 \%$. When second TSS was performed in five patients with persistent $C D$ the remission rate was $0 \%$, but it was $50 \%$ in four patients with recurrent hypercortisolism. Moreover, some patients could experience a late decrease in cortisol levels and remission could not be established during the early postoperative period, and others achieved longterm remission even with cortisol levels above $2 \mathrm{mg} / \mathrm{dl}$ $(50 \mathrm{nmol} /$ liter $)(4,39)$. We could speculate that those 5 patients in Locatteli's series who achieved remission after second TSS without tumor found during the surgery, could be already in remission of CD after the first operation. Thus, we do not recommend repeat TSS in persistent CD, mainly during this initial postoperative period.

In conclusion, TSS for CD is an effective and safe treatment, with good remission rates and few serious complications. The best remission rates were observed at the first surgery and in microadenomas. The low remission rates after a second TSS suggest that this approach could not be a good therapeutic choice when the first one was not curative. Late recurrence can occur and patients should be monitored closely to ensure successful and adequate long-term treatment and outcome.

\section{REFERENCES}

1. Arnaldi G, Angeli A, Atkinson AB, Bertagna $X$, Cavagnini $F$, Chrousos GP, et al. Diagnosis and complications of Cushing's syndrome: A consensus statement. J Clin Endocrinol Metab 2003;88: 5593-602.

2. Mancini T, Kola B, Mantero F, Boscaro M, Arnaldi G. High cardiovascular risk in patients with Cushing's syndrome according to 1999 WHO/ISH guidelines. Clin Endocrinol 2004;61: 768-77.
3. Findling JW, Raff H. Clinical review: Cushing's syndrome: Important issues in diagnosis and management. J Clin Endocrinol Metab 2006;91:3746-53.

4. Esposito F, Dusick JR, Cohan P, Moftakhar P, McArthur D, Wang $C$, et al. Early morning cortisol levels as a predictor of remission after transsphenoidal surgery for Cushing's disease. J Clin Endocrinol Metab 2006;91:7-13.

5. Laws ER, Reitmeyer M, Thapar K, VanceML. Cushing's disease resulting from pituitary corticotrophic microadenoma. Treatment results from transsphenoidal microsurgery and gamma knife radiosurgery. Neurochirurgie 2002;48:294-9.

6. Semple PL, Vance ML, Findling JW, Laws ER. Transsphenoidal surgery for Cushing's disease: outcome in patients with a normal magnetic resonance imaging scan. Neurosurgery 2000;46:553-9.

7. Oldfeld EH. Cushing disease. J Neurosurg 2003;98:948-51.

8. Chen JC, Amar AP, Choi S, Singer P, Couldwell WT, Weiss $\mathrm{MH}$. Transsphenoidal microsurgical treatment of Cushing disease: postoperative assessment of surgical efficacy by application of an overnight low-dose dexamethasone suppression test. J Neurosurg 2003;98:967-73.

9. Reitmeyer M, Vance ML, Laws Jr ER. The neurosurgical management of Cushing's disease. Mol Cell Endocrinol 2002;197:73-9.

10. Salassa RM, Laws ER, Carpenter PC, Northcutt RC. Cushing's disease - 50 years later. Trans Am Clin Climatol Assoc 1982;94:122-9.

11. Semple CG, Thomson JA, Teasdale GM. Transsphenoidal microsurgery for Cushing's disease. Clin Endocrinol (Oxf) 1984;21:621-9.

12. Shimon I, Ram Z, Cohen ZR, Hadani M. Transsphenoidal surgery for Cushing's disease: endocrinological follow-up monitoring of 82 patients. Neurosurgery 2002;51:57-62.

13. Zada G, Kelly DF, Cohan P, Wang C, Swerdloff R. Endonasal transsphenoidal approach for pituitary adenomas and other sellar lesions: an assessment of efficacy, safety, and patient impressions. J Neurosurg 2003;98:350-8.

14. Bochicchio D, Losa M, Buchfelder M. Factors influencing the immediate and late outcome of Cushing's disease treated by transsphenoidal surgery: a retrospective study by the European Cushing's Disease Survey Group. J Clin Endocrinol Metab 1995;80:3114-20.

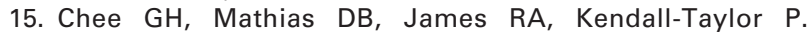
Transsphenoidal pituitary surgery in Cushing's disease: can we predict outcome? Clin Endocrinol (Oxf) 2001;54:61726.

16. Dickerman RD, Oldfield EH. Basis of persistent and recurrent Cushing disease: an analysis of findings at repeated pituitary surgery. J Neurosurg 2002;97:1343-9.

17. Lamberts SW, van der Lely AJ, de Herder WW. Transsphenoidal selective adenomectomy is the treatment of choice in patients with Cushing's disease. Considerations concerning preoperative medical treatment and the long-term follow-up. J Clin Endocrinol Metab 1995;80:3111-3.

18. Mampalam TJ, Tyrrell JB, Wilson CB. Transsphenoidal microsurgery for Cushing disease. A report of 216 cases. Ann Intern Med 1988;109:487-93.

19. Pereira AM, van Aken MO, van Dulken H, Schutte PJ, Biermasz NR, Smit JW, et al. Long-term predictive value of postsurgical cortisol concentrations for cure and risk of recurrence in Cushing's disease. J Clin Endocrinol Metab 2003;88:5858-64.

20. Rees DA, Hanna FW, Davies JS, Mills RG, Vafidis J, Scanlon MF. Long-term follow-up results of transsphenoidal surgery for Cushing's disease in a single centre using strict criteria for remission. Clin Endocrinol (Oxf) 2002;56:541-51.

21. Sheehan JM, Lopes MB, Sheehan JP, Ellegala D, Webb KM, Laws Jr ER. Results of transsphenoidal surgery for Cushing's disease in patients with no histologically confirmed tumor. Neurosurgery 2000;47:33-9.

22. Simmons NE, Alden TD, Thorner MO, Laws Jr ER. Serum cortisol response to transsphenoidal surgery for Cushing disease. J Neurosurg 2001;95:1-8. 
23. Trainer PJ, Lawrie HS, Verhelst J, Howlett TA, Lowe DG, Grossman AB, et al. Transsphenoidal resection in Cushing's disease: undetectable serum cortisol as the definition of successful treatment. Clin Endocrinol (Oxford) 1993:38:73-8.

24. Estrada J, Garcia-Uria J, Lamas C, Alfaro J, Lucas T, Diez S, et al. The complete normalization of the adrenocortical function as the criterion of cure after transsphenoidal surgery for Cushing's disease. J Clin Endocrinol Metab 2001;86:5695-9.

25. Flitsch J, Knappe UJ, Ludecke DK. The use of postoperative ACTH levels as a marker for successful transsphenoidal microsurgery in Cushing's disease. Zentralbl Neurochir 2003:64:6-11.

26. Yap LB, Turner HE, Adams CB, Wass JA. Undetectable postoperative cortisol does not always predict long-term remission in Cushing's disease: a single centre audit. Clin Endocrinol (Oxford) 2002;56:25-31.

27. Ram Z, Nieman LK, Cutler Jr GB, Chrousos GP, Doppman JL, Oldfield EH. Early repeat surgery for persistent Cushing's disease. J Neurosurg 1994;80:37-45.

28. Hammer GD, Tyrrell JB, Lamborn KR, Applebury CB, Hannegan ET, Bell S, et al. Transsphenoidal microsurgery for Cushing's disease: initial outcome and long-term results. $\mathbf{J}$ Clin Endocrinol Metab 2004;89:6348-57.

29. Swearingen B, Biller BM, Barker 2nd FG, Katznelson L, Grinspoon S, Klibanski A, et al. Long-term mortality after transsphenoidal surgery for Cushing disease. Ann Intern Med 1999;130:821-4.

30. Blevins Jr LS, Christy JH, Khajavi M, Tindall GT. Outcomes of therapy for Cushing's disease due to adrenocorticotropinsecreting pituitary macroadenomas. J Clin Endocrinol Metab 1998;83:63-7.

31. Cannavo S, Almoto B, Dall'Asta C, Corsello S, Lovicu RM, De Menis $E$, et al. Long-term results of treatment in patients with ACTH-secreting pituitary macroadenomas. Eur J Endocrinol 2003;149:195-200.

32. Damiani D, Aguiar CH, Crivellaro CE, Galvão JA, Dichtchekenian V, Setian N. Pituitary macroadenoma and Cushing's disease in pediatric patients: patient report and review of the literature. J Pediatr Endocrinol Metab 1998;11:665-9.

33. Semple PL, Laws Jr ER. Complications in a contemporary series of patients who underwent transsphenoidal surgery for Cushing's disease. J Neurosurg 1999;91:175-9.

34. Ciric I, Ragin A, Baumgartner C, Pierce D. Complications of transsphenoidal surgery: results of a national survey, review of the literature, and personal experience. Neurosurgery 1997;40:225-36; discussion 236-7.

35. Guilhaume B, Bertagna X, Thomsen M, Bricaire C, Vila-Porcile $E$, Olivier $L$, et al. Transsphenoidal pituitary surgery for the treatment of Cushing's disease: results in 64 patients and long term follow up studies. J Clin Endocrinol Metab 1988;66:1056-64.

36. Lamberts SWJ, van der Lely AJ, de Herder WW. Transsphenoidal selective adenomectomy is the treatment of choice in patients with Cushing's disease. Considerations concerning preoperative medical treatment and the long follow up. J Clin Endocrinol Metab 1995;80:3111-3.

37. Massoud AF, Powell M, Williams RA, Hindmarsh PC, Brook CG. Transsphenoidal surgery for pituitary tumours. Arch Dis Child 1997;76:398-404.

38. Hoybye C, Grenback E, Thoren M, Hulting A, Lundblad L, Von Holst $\mathrm{H}$, et al. Transsphenoidal surgery in Cushing disease: 10 years of experience in 34 consecutive cases. J Neurosurg 2004; 100:634-8.

39. Rollin GAFS, Ferreira NP, Junges M, Gross JL, Czepielewski MA. Dynamics of serum cortisol levels after transsphenoidal surgery in a cohort of patients with Cushing's disease. J Clin Endocrinol Metab 2004;89:1131-9.

40. Hofmann BM, Fahlbusch R. Treatment of Cushing's disease: A retrospective clinical study of the latest 100 cases. In: Laws ER Jr, Sheehan JP (eds). Pituitary Surgery - A Modern Approach. vol 34. Basel: Karger, 2006. pp. 158-84.
41. Netea-Maier RT, van Lindert EJ, den Heijer M, van der Eerden A, Pieters GFFM, Sweep CGJ, et al. Transsphenoidal pituitary surgery via the endoscopic technique: results in 35 consecutive patients with Cushing's disease. Eur $J$ Endocrinol 2006;154:675-84.

42. Hardy J. Cushing's disease: 50 years later. Can J Neurol Sci 1982;4:375-80.

43. Sonino N, Zielezny M, Fava GA, Fallo F, Boscaro M. Risk factors and long-term outcome in pituitary-dependent Cushing's disease. J Clin Endocrinol Metab 1996;81:2647-52.

44. Pieters GF, Hermus AR, Meijer E, Smals AG, Kloppenborg PW. Predictive factors for initial cure and relapse rate after pituitary surgery for Cushing's disease. J Clin Endocrinol Metab 1989;69:1122-6.

45. Barbetta L, Dall'Asta C, Tomei G, Locatelli M, Giovanelli M, Ambrosi B. Assessment of cure and recurrence after pituitary surgery for Cushing's disease. Acta Neurochir (Wien) 2001;143:477-81; discussion 481-2.

46. Invitti C, Giraldi FP, de Martin M, Cavagnini F. Diagnosis and management of Cushing's syndrome: results of an Italian multicentre study. Study Group of the Italian Society of Endocrinology on the Pathophysiology of the HypothalamicPituitary-Adrenal Axis. J Clin Endocrinol Metab 1999;84:440-8.

47. Utz AL, Swearingen B, Biller BM. Pituitary surgery and postoperative management in Cushing's disease. Endocrinol Metab Clin North Am 2005;34:459-78.

48. Acebes JJ, Martino J, Masuet C, Montanya E, Soler J. Early post-operative ACTH and cortisol as predictors of remission in Cushing's disease. Acta Neurochir (Wien) 2007; $149: 471-7$

49. Locatelli M, Vance ML, Laws ER. Clinical review: the strategy of immediate reoperation for transsphenoidal surgery for Cushing's disease. J Clin Endocrinol Metab 2005;90:54782.

50. Melby JC. Therapy of Cushing's disease: a consensus for pituitary microsurgery. Ann Intern Med 1988;109:445-6.

51. Zervas NT. Reflections on the surgery of the pituitary. Clin Neurosurg 1980;27:124-32.

52. Friedman RB, Oldfield EH, Nieman LK, Chrousos GP, Doppman JL, Cutler GB, et al. Repeat transsphenoidal surgery for Cushing's disease. J Neurosurg 1989;71:520-7.

53. Benveniste RJ, King WA, Walsh J, Lee JS, Delman BN, Post KD. Repeated transsphenoidal surgery to treat recurrent or residual pituitary adenoma. J Neurosurg 2005;102:1004-12.

54. Pouratian N, Prevedello DM, Jagannathan J, Lopes MB, Lee Vance M, Laws Jr. ER. Outcomes and management of patients with Cushing's disease without pathological confirmation of tumor resection after transsphenoidal surgery. J Clin Endocrinol Metab 2007:92:3383-8.

55. Rollin G, Czepielewski MA. Cushing's syndrome: Is it possible a standard and simple diagnostic approach? Arq Bras Endocrinol Metab 2003;47:368-80.

56. Bakiri F, Tatai S, Aouali R, Semrouni M, Derome P, Chitour F, et al. Treatment of Cushing's disease by transsphenoidal, pituitary microsurgery: prognosis factors and long-term follow-up. J Endocrinol Invest 1996;19:572-8.

57. Comtois R, Beauregard H, Hardy J, Robert F, Somma M. High prolactin levels in patients with Cushing's disease without pathological evidence of pituitary adenoma. Clin Endocrinol (Oxford) 1993;38:601-7.

\section{Address for correspondence:}

Guilherme Rollin

Rua Engenheiro Afonso Cavalcanti 135/501

90440-110 Porto Alegre, RS

E-mail: guilhermerollin@ibest.com.br 